\title{
An explanation of cross-national variation in call centre job quality using institutional theory
}

\section{David Holman}

\section{Contact Details:}

David Holman

Manchester Business School

Booth St East

Manchester

M21 6PB

Tel: +44-161-881-3797

Email: david.holman@mbs.ac.uk 


\begin{abstract}
Employment regime theory is used to examine whether cross-national variation in call centre job quality is a result of differences in national institutional regime, i.e., inclusivist, dualist, and market regimes. Analysis of an establishment-level survey of 1734 call centres revealed that, as expected, call centre job quality was highest in inclusivist regimes (Denmark, Sweden) and higher in dualist regimes (Austria, France) than in market regimes (Canada, UK, USA). Job quality in Germany, a dualist regime, was of a similar level to that in inclusivist regimes. There was also evidence that, only within dualist regimes, job quality was higher in call centres attached to larger firms than in independent call centres. The findings suggest that national institutional regimes are still sufficiently different and influential to produce cross-national variations in job quality and have not been weakened and homogenised as a result of the internationalization of national economies.
\end{abstract}

Key words: call centres, employment regime theory, job quality 
Should we expect the general level of job quality in call centres to differ between countries? For example, are we more likely to find high quality jobs in Swedish call centres than in German, British or American call centres? According to employment regime theory, call centre job quality should differ between countries when countries have different national institutional regimes. Employment regime theory proposes that this will occur because a country's institutional regime influences the national level of job quality, such that national differences in institutional regime lead to cross-national variation in job quality (Gallie, 2007).

However, the call centre industry has certain features which call in to question whether the national institutional regimes in which call centres developed were sufficiently different and sufficiently influential to cause cross-national variation in call centre job quality. One important feature of the call centre industry is that it has developed largely over the last fifteen years: a time characterised by the increasing internationalization and liberalization of national economies (particularly in the financial sector where many call centres are located) and an increasing level of regional integration, e.g., EU working directives (Bosch et al, 2009; Katz \& Derbishire, 2000). These changes suggest that a degree of convergence in national institutional regimes occurred during the time in which call centres developed, which would reduce the extent of cross-national variation in call centre job quality. Another feature of the call centre industry is that some call centres were set up in a direct attempt to escape perceived institutional constraints (Haipeter \& Pernod-Lemattre, 2005), which implies that national institutional regimes may have had little influence on call centre jobs. Both of these features of the call centre industry suggest that national differences in call centre job quality may not be related to national differences in institutional regimes and, as such, that any pattern of cross-national variation in call centre job quality will be different to that predicted by employment regime theory. Given these alternative perspectives, the main aim of this paper is to examine whether employment regime theory predicts cross-national variation in call centre job quality.

A further reason for studying institutional influences on call centre job quality is that, although many call centres offer low quality jobs that typically combine low discretion, pay, skill requirements, training with high task monitoring (Holman, Chissick, \& Totterdell, 2002; Holman, Batt, \& Holtgrewe, 2007; Rubery et al., 2004; Taylor, Baldry, Bain \& Ellis, 2003; Taylor, Hyman, Mulvey \& Bain, 2002), there is a degree of variation in job quality between different forms of call centres, e.g., bureaucratic call centres with low quality jobs and 
professional call centres with high quality jobs (Holman, Frenkel, Sørensen, \& Wood, 2009; Batt, 2002; Frenkel, Korczyniski, Shire \& Tam, 1999). Knowing why certain call centres have higher quality jobs is clearly important, not only in helping to gain a better understanding of the factors that might give rise to different forms of call centre organisation but also practically, as such knowledge can help policy makers to formulate effective job quality improvement strategies.

A key issue in the study of job quality is how it should be measured. In this paper, job quality is understood to be a multi-dimensional construct, with the five main dimensions of job quality being: work organisation; skills and development opportunities; wages and the payment system; security and flexibility; and, collective representation and voice (Bustillo et al, 2009; Green, 2006). A multi-dimensional understanding of job quality has two important measurement implications (Tangian, 2007). The first is that a measure of job quality should reflect the five main dimensions of job quality. The second concerns how to weight the different constituent parts of a job quality measure, which is needed because some parts of a job have a relatively greater effect on outcomes than others and therefore make a relatively greater contribution to job quality (Humphrey et al, 2007). The second aim of this paper is to deal with these measurement issues by developing a total job quality measure in which the constituent parts reflect the five main dimensions of job quality and in which each part is weighted using a criterion-based weighting procedure.

This paper contributes to the literature on institutional theory by being the first to examine cross-national variation in the total quality of a job, which contrasts with previous cross-national institutional studies of job quality that focus only on a particular dimension of job quality, e.g., work organisation or training (Gallie, 2009; Holman, Frenkel, Sørensen, \& Wood, 2009; Goergen et al., 2009). Another novel aspect of this paper is that it compares job quality across non-European countries (i.e., the US and Canada) and a broad range of European countries (i.e., UK, Germany, France, Austria, Denmark and Sweden). This contrasts with previous institutional studies of job quality that have focused only on European countries (e.g., Gallie, 2009; Goergen et al., 2009), or compare non-European countries with a limited range of European countries (e.g., Dobbin \& Boychuk, 1999, only include Nordic countries); thereby providing a strong test of the generalisability of employment regime theory. The paper further contributes to the institutional literature by being the first to test employment regime theory in 
the call centre industry; and as call centres are a relatively new and emerging part of the economy, this study provides a contemporary test of employment regime theory. In addition, this paper contributes to the literature on measuring job quality by setting out a new procedure for developing a weighted job quality measure.

Before I discuss how employment regime theory can be used to explain cross-national variation in call centre job quality, I start by providing a more detailed definition of job quality.

\section{Defining Job Quality}

There are two main approaches to defining job quality. An objectivist approach focuses on objective features of the job and assumes that these are the predominant cause of employee experiences, e.g., employee well-being. In contrast, a subjectivist approach focuses on employee work preferences and their perceived fulfilment (Brown, Charlwood, Forde \& Spencer, 2007; Bustillo, et al., 2009). An objectivist approach to job quality is adopted, as objective work conditions have been shown to shape the experience of work over and above personal preferences (Green, 2006; Parker \& Wall, 1999) and because employee experiences cannot be defined solely in terms of preference fulfilment or satisfaction (Sen, 1985).

In keeping with the objectivist approach, job quality is defined as the extent to which a job has factors that foster beneficial outcomes for the employee or the organization (Green, 2006; Sen, 1985; Tangian, 2007). One of the main beneficial outcomes of a high quality job for employees is typically considered to be a high level of psychological well-being, i.e., the experience of longer-term levels of pleasant affect such as enthusiasm and contentment, and a lack of unpleasant affect such as anxiety and depression (Warr, 1990). High employee wellbeing may also reduce the likelihood of an employee voluntary quitting his or her job because, unlike employees with low well-being, employees with high well-being have less need to use coping strategies such as withdrawal behaviours (i.e., from the organisation) and situation modification (i.e., changing one's organisational context) as a way of trying to improve their well-being (Deery, Iverson \& Walshe, 2002; Griffeth et al, 2000; Lee, Mitchell, Wise, \& Fireman, 1996; Wright \& Bonett, 2007; Wright \& Cropanzano, 1998). Organisations with higher quality jobs are therefore likely to have higher levels of employee well-being and, as a result, a lower quit rate (i.e., the percentage of employees who voluntarily leave their job in a year excluding promotions, internal transfers, dismissals, and retirements); and this means that a 
low quit rate can be understood as a beneficial organisational-level outcome of job quality. The job factors that foster these beneficial outcomes (i.e., employee well-being, low quit rates), and which are therefore indicators of job quality, can be classified according to five dimensions: work organisation, e.g., job design (such job discretion, job demands) and team design (participation in off-line teams); skills and development, e.g., training, opportunity for development; wage and payment system; security and flexibility, e.g., contract type, flexible working arrangements; and collective representation and voice, e.g., a trade union agreement, employee participation practices (Bustillo, et al., 2009; Tangian, 2007). Each of these dimensions has also been identified as being an important aspect of call centre job quality (Holman, et al., 2007; Frenkel et al., 1998; Sprigg \& Jackson, 2006; Rubery et al., 2004; Taylor et al., 2003; Taylor et al., 2002).

\section{Employment regime theory and job quality}

Institutional theories assert that a country's institutional regime will influence the level of job quality in that country such that national differences in institutional regimes should lead to cross-national variation job quality (Gallie, 2007; Holman et al., 2009). One key institutional approach is varieties of capitalism theory, which distinguishes liberal institutional regimes (e.g., UK, US) from coordinated regimes (e.g., Germany, France and Nordic countries) on the basis of how organisations coordinate their actions with other actors (Hall and Soskice, 2001). Another key institutional approach is employment regime theory which distinguishes between market regimes (e.g., UK, US), dualist regimes (e.g., Germany France) and inclusivist regimes (e.g., Nordic countries) on the basis of national employment policies and the relative capacity of organized labour (Esping-Anderson, 1990; Gallie, 2007; Korpi, 2006). This paper uses employment regime theory as it provides a clear account of how institutional factors influence job quality and because it is supported by empirical evidence with regard to cross-national differences in specific aspects of job quality such as work organisation (Gallie, 2009; Goergen et al., 2009). However, although employment regime theory predicts that there should be crossnational differences in the total quality of a job, this proposition has yet to be tested.

Employment regime theory indentifies three key types of national institutional regimes in western developed economies and asserts that each regime can be differentiated in terms of its employment policies (e.g., full employment policies, employment rights, welfare provision) and 
the relative capacity of organized labour (Esping-Anderson, 1990; Gallie, 2007; Korpi, 2006). Inclusivist regimes (e.g., Sweden, Denmark) are characterised as having policies designed to extend employment rights and employment throughout the working-age population. Dualist regimes (e.g., Germany, Austria, and France) are characterised by strong employment rights for a core workforce of long-term skilled employees but much weaker rights for those on the periphery, and with less concern over employment levels. Market regimes (e.g., UK, US and Canada) are characterised by little employment regulation and it is assumed that the market will lead eventually to high employment levels.

Employment regime theory sets out how institutional features differ between countries and how they influence job quality. In inclusivist regimes, the participation of organised labour in decision making is seen to be highly institutionalised within organisations (e.g., works councils) and the party in government; and that central aims of organised labour are to promote employment growth and high levels of employment, to collaborate with employers in developing industry specific and vocational training programmes, and to curb pay differentials and enhance the pay of low paid workers (Culpepper \& Thelen, 2007; Gallie, 2000; Kristensen \& Lilja, 2010). A strategy to promote employment growth and high levels of employment will, if successful, protect union members from unemployment, increase the value of employees' skills and make the labour market much tighter. One likely outcome of a tight labour market will be to increase the capacity of employees and organised labour to secure better job conditions (e.g., work organisation) and employment conditions (e.g., basic wage levels, job security, flexible working arrangements), to gain greater influence in workplace decision-making and to resist practices deemed deleterious to well-being, e.g., standardization, excessive monitoring (Dobbin $\&$ Boychuk, 1999; Gustavson, 2007). The aim of organised labour to promote training may lead to a more highly skilled workforce (Lasonen \& Rauhala, 2000), which may not only help to secure higher wage levels but may also permit the design of more complex jobs (Prais et al., 1989). Complex jobs typically have high levels of discretion and tend to be intrinsically motivating, and the resulting commitment means that employees are likely to require less direct control and monitoring (Parker \& Wall, 1999). Furthermore, if unions are successful in curbing pay differentials and enhancing the pay of low paid workers, wage dispersion is likely to be dampened (Wallerstein, 1999). Finally, welfare policies in inclusivist regimes are designed to promote participation in the workforce of women and vulnerable groups (Epsing-Andersen, 
1990), which may help to reduce differences in job and employment conditions between different categories of employees, e.g., men/women, part-time/full-time (Mandel \& Semyonov, 2006). In summary, it can be suggested an inclusivist regime is likely to promote job factors that are indicative of high job quality.

In dualist regimes, employment regime theory asserts that organised labour has a more consultative role within organisations and that its influence is partly dependent upon the party of government. This implies that organised labour will have a weaker capacity to realise its aims, such as promoting skill levels and wage rates. Another implication is that organised labour is likely to be strongest in those areas of the economy where it can easily mobilize the workforce, such as the core employees of large firms (Culpepper, 1999; Hyman, 2001). As a result, employment and working conditions may be better among the core employees of large firms than among employees with non-standard contracts or those working in smaller firms (Streeck, 1991; Thelan \& Kume, 1999). The overall level of job quality in dualist regimes is therefore likely to be lower than that in inclusivist regimes for two reasons. First, even in the core workforce, organised labour has less capacity to secure better employment conditions. Second, employment conditions will be lower in certain parts of the economy and therefore depress the overall mean.

In market regimes, employment regime theory suggests that little state intervention occurs with regard to the regulation of working conditions and that this is partly because many institutional actors (e.g., employers, employments associations) assume that employment conditions and employment levels are best regulated by the market (Gallie, 2007). Organised labour has little involvement in decision-making within firms or the government, partly because some institutional actors view it as a competing interest group (Hyman, 2001). This reduces the capacity of organised labour to influence employment and working conditions. The lower levels of employment protection and employment create a relatively fluid labour market, which may make employers less willing to train because returns on such investments are less likely (Capelli et al., 1997; Finegold \& Soskice, 1988). In turn, the lower skill level of employees inhibits the design of more complex jobs, which is likely to lead to jobs with lower discretion, higher levels of standardization and lower wage rates (Prais et al, 1989). As a result of these institutional features, market regimes appear likely to produce a lower level of job quality than that found in inclusivist or dualist regimes. 
By drawing on employment regime theory it can therefore be proposed that the total quality of a job should be higher in inclusivist regimes than in dualist and market regimes, while the total quality of a job in dualist regimes should be higher than in market regimes. Empirical support for this comes from European employee-level studies comparing job quality between institutional regimes, which show inclusivist regimes to have better work organisation, e.g., higher task discretion (Gallie, 2009), higher levels of training, particularly for clerical employees (Goergen et al, 2010), and lower wage dispersion (Gallie, 2009) than dualist and market regimes. Establishment-level studies of call centres also show that call centre jobs in inclusivist regimes have higher security and flexibility than those in dualist and market regimes (Batt \& Nohara, 2009; Holman et al., 2007). Call centre jobs in inclusivist and dualist regimes also have better quality work organisation (e.g., high task discretion, lower monitoring) and higher levels of collective representation than call centres in market regimes (Holman et al., 2007; Holman et al., 2009). The pattern that emerges from these studies is that different aspects of job quality tend to be higher in inclusivist regimes than in dualist and market regimes, and to be higher in dualist regimes tends to be higher than in market regimes. But not all aspects of job quality have been included in studies comparing job quality between institutional regimes and no study has yet to compare the total quality of a job between these three types of regime.

Overall, there are theoretical and empirical reasons to expect the total quality of call centre jobs to differ between countries with inclusivist, dualist and market regimes. As such, we set the following two hypotheses:

Hypothesis 1: The mean level of call centre job quality will be higher in inclusivist regimes than in both dualist and market regimes.

Hypothesis 2: The mean level of call centre job quality will be higher in inclusivist and dualist regimes than in market regimes.

Employment regime theory also predicts that, within dualist regimes, job quality should be higher in firms where organised labour has a greater capacity to influence decision-making, e.g., in large firms, in core employees within firms. There is some evidence to support this with regard to permanent employees in Germany, who have higher task discretion than temporary employees (Gallie, 2007). In the call centre industry, it is possible to distinguish between call 
centres that are part of a larger firm, (e.g., the call centre of a bank or large subcontractor) and those that are not, e.g., independent single site call centres specializing in call centre services. Thus, during the development of the call centre industry in dualist regimes, the historical involvement of organised labour in large organisations would increase the likelihood of organised labour having an influence on working conditions and employment regulation; whereas in new independent call centres, organised labour might find it harder to influence working conditions. For this reason, job quality within dualist regimes may be higher in call centres that are part of a larger firm than that in independent single site call centres. The polarization of job quality between these two types of call centre should not occur in inclusivist employment regimes or in market employment regimes because the influence of organised labour should be uniform across these different parts of the economy. The third hypothesis of this study is:

Hypothesis 3: Within dualist regimes, the mean level of job quality will be higher in call centres that are part of a larger firm than in independent single site call centres.

\section{Measuring job quality}

Assessments of the total level of job quality need to reflect its multi-dimensional nature. This can be achieved by developing an aggregated job quality measure based on indicators that reflect the five main dimensions of job quality. A central issue when creating an aggregated job quality measure is how to weight its constituent parts. Weighting is important because some parts of a job are likely to have a relatively greater effect on outcomes, such as well-being or quit rates, than others. Certain parts of the job therefore make a greater contribution to job quality and this should be reflected in an aggregate job quality measure. For example, if job discretion accounts for more of the variance in employee well-being than training, this implies that job discretion makes a greater contribution to job quality than training and that job discretion should be weighted more heavily than training in a job quality measure. Furthermore, certain job characteristics may make a positive contribution, while others may make a negative contribution. These different effect valences also need to be accounted for in the weighting process. Interestingly, some authors decide not to weight when creating aggregated job quality measures, as they believe there is no reliable basis for weighting (Tangian, 2007). But a non-weighted job 
quality measure is problematic as it is based on the assumption that all constituent parts contribute positively, equally and independently to job quality; and this may result in a particular job factor being over or under represented in a total job quality measure and result in the total level of job quality being specified incorrectly.

A number of different approaches to weighting are possible. Subjectively-based weighting procedures derive weights from subjective judgements (e.g., Leschke \& Watt, 2008) but such judgements lack a theoretical or empirical basis, which may lead to weights being specified incorrectly. Criterion-based weighting procedures derive weights from the nature of the relationship (e.g., size, direction) between an independent variable and a criterion measure. An advantage of this approach is that weights are derived empirically from the data, thereby providing a reasonably objective approach to weight estimation. In this paper, weights will be based on the variance of a criterion that is uniquely explained by a job factor and on the valence of the relationship between job factor and criterion. For example, if job discretion explains five percent of the variance in a beneficial outcome of a job (e.g., employee well-being or a low quit rate) and the relationship between them is positive, then the job discretion measure would be weighted by .05. Furthermore, as the data in this paper is derived from an organisational-level survey, the criterion used in this paper will be quit rate which, as outlined earlier, can be classed as a beneficial organisational-level outcome of job quality (Deery et al., 2002; Griffeth et al, 2000; Wright \& Bonnett, 2007). Thus, the measure used in this paper will be an aggregated weighted job quality measure, in which each constituent part has been weighted according to the unique percentage of variance that it explains in quit rate and the valence of its relationship to quit rate. The weighted job quality measure therefore represents the extent to which a job has a combination of factors that are likely to promote a beneficial outcome (i.e., a low quit rate) and this measure is, crucially, in keeping with the definition of job quality outlined earlier.

\section{METHOD}

\section{Sample \& Procedure}

The sample used in this paper is derived from the Global Call Centre project's survey of human resource management in call centres (Holman et al., 2007). The establishment-level survey was conducted in seventeen countries. Different methods of survey administration were 
used, including mail, internet, and telephone interview. Survey questions were answered by a senior call centre manager. Stratified samples were drawn from the total population of call centres when this was known (e.g., US) but as this was not possible in most countries, call centres were identified from the lists of national call centre associations. The average response rate was $72 \%$.

The sample used in this study is 1734 call centres drawn from eight countries: Denmark, Sweden, Austria, France, Germany, UK, Canada, and the USA. These countries were selected as they are clearly identifiable as having institutional regimes of the type set out in employment regime theory. The other nine countries from the total sample were excluded because of missing data on key variables (e.g., Netherlands), or because of a small sample size (Ireland) or because they represented emerging market economies and it is not clear how to classify them according to employment regime theory (e.g., Brazil, India).

\section{Measures}

Weighted job quality measure. The weighted job quality measure was created in six steps. First, twelve measures were chosen from the data set that reflected the five main dimensions of job quality in call centres (Holman et al., 2007; Batt, 2002; Taylor et al., 2002). The full details of these measures can be seen in Table 1. Second, the unique percentage of variance explained by each measure with regard to quit rate was calculated using relative weight analysis (which takes into account any multicollinearity between independent variables and is thus preferable to weights based on standard regression procedures that do not, Johnson, 2001) with the twelve aforementioned measures as independent variables and quit rate (the log-transformed estimate of the percentage of employees who voluntarily left their job in the previous year excluding promotions, internal transfers, dismissals, and retirements) as the criterion variable. (Quit rate was used as the criterion variable in this study as the data is derived from an organisational level survey and, as outlined earlier, it can be understood as a beneficial organisational-level outcome of job quality). The quit rate measure was reverse scored, so high scores indicated lower quit rates. The means and weights of each measure are shown in Table 1. Third, all measures were standardized to have the same scale. If this is not done, then measures with a higher scale will be over represented in the final score. The presence of binary variables meant that all variables had to be standardized to be a dichotomous score of either one or two. Continuous measures were dichotomised around the median score. Fourth, the standardized measures were multiplied by 
the appropriate weight, with the valence of the weight reflecting the valence of the correlation between the independent variable and criterion. For example, job discretion was multiplied by .063 , while performance monitoring was multiplied by -.053 . Fifth, the mean score of the twelve weighted measures was calculated. Finally, to ease interpretation, the mean score was normalised such that the weighted job quality measure has a range from 0 to 100 . Based on the recommendation of Tangian (2007) we normalised the score using the following formula $\mathrm{y}=(x-$ $x \min / x \max -x \min )^{*} 100$; where $x$ is the mean score. In this formula, the normalised score, $y$, represents the percentage of the absolute maximum.

\section{TABLE 1 HERE}

Unweighted job quality measure. To compare the performance of the weighted job quality measure, an unweighted job quality measure was created using the same procedure as above, except that step four was omitted. The unweighted job quality measure represents the normalized mean of the twelve standardized job quality measures.

Type of economy. Based on Gallie's analysis (2007) we coded each country as an inclusivist (Sweden and Denmark), dualist (Germany, France, Austria) or market (United States, the United Kingdom, Canada) employment regime.

Call centre characteristics. A binary dummy variable was used for the measure of whether the call centre was part of a larger organization or an independent entity (Dummy coded 1 and 0 ). This measure was also used as a control variable when appropriate, as were the following call centre characteristics; size (the total number of full-time equivalent employees, $\log$ transformed); market sector (financial services, public sector); subcontractor or in-house call centre; handling predominantly inbound or outbound calls; and whether the call centre predominantly served business market customers or mass market customers. These variables were included as controls, as cross-national differences in markets, customer type or service type might also account for cross-national differences in job quality (Holman et al., 2009: Frenkel, et al., 1999).

\section{RESULTS}


Descriptive data pertaining to the job factors (means, weights) that comprise the job quality measure can be seen in Table 1 . Correlations between the main study variables can be seen in Table 2. The weighted and unweighted job quality scores can be seen in Table 3, which shows the weighted job quality measure to be highest in inclusivist regime countries, lowest in the market regime countries, and at a level between these two groups in dualist countries. This clear pattern is not evident in the unweighted job quality score.

\section{TABLE 2 HERE}

\section{TABLE 3 HERE}

Hypothesis 1 stated that job quality will be higher in inclusivist regimes than in both dualist and market regimes. Hypothesis 2 stated that job quality will be higher in inclusivist and dualist regimes than in market regimes. These hypotheses were tested simultaneously using an ANCOVA with weighted job quality as the dependent variable, country as the independent variable and all control variables as covariates. The result indicated significant differences in job quality between countries $(\mathrm{F}=(7,1618) 42.49, p<.01)$. Post-hoc comparisons revealed that inclusivist regime countries (Denmark, Sweden) have significantly higher job quality than all the dualist regime countries except Germany and that inclusivist regime countries have significantly higher job quality than all the market regime countries (all comparisons $p<.05$ or greater). Hypothesis 1 was only partially confirmed. The post-hoc comparisons also revealed that job quality in all inclusivist and dualist regime countries is significantly higher than in all market regime countries (all comparisons $p<.05$ or greater). Hypothesis 2 was fully confirmed. A repeat analysis with the unweighted job quality did not find this systematic pattern of differences: the main differences being that the UK was significant lower, and the US significantly higher, than most other countries $(p<.05)$.

Hypothesis 3 proposed that, in dualist regimes, the level of job quality would be higher in call centres that are part of a larger organisation than in independent call centres. This was examined using an ANCOVA similar to that described above but with an additional interaction between the country measure and the measure of whether the call centre was part of a larger organisation or not. The results revealed a significant interaction effect $(F=(7,1624) 2.27, p<$ 
.05) indicating that the differences between the two types of call centre (i.e., part of a larger organisation or independent) were greater in some countries than in other countries. The adjusted weighted job quality scores from this analysis are shown in columns four and five of Table 3 and are plotted in Figure 1. The plotted means in Figure 1 indicate that the level of job quality in each dualist country is higher in call centres that are part of a larger organisation. A regression was then conducted on the sample of call centres in dualist regimes to examine if this difference was significant. This regression included weighted job quality as the dependent variable, and the independent variables were the measure of whether the call centre was part of a larger organisation or not, and all controls. The results confirmed that, in dualist regimes, the level of job quality is significantly higher in call centres that are part of a larger organisation than in independent call centres $(\beta=.15, p<.01)$. But this result does not confirm Hypothesis 3 , as it also needs to be shown that this particular pattern does not occur in inclusivist and market regime countries. This was tested using two similar regressions, one on the sample of inclusivist regime countries, and the other on the sample of market regime countries. With regard to inclusivist regime countries, the results found no significant differences between the two types of call centre $(\beta=-.13$, n.s. $)$. The results for market regime countries found that job quality is lower in call centres that are part of a larger organisation than in independent call centres $(\beta=-.06, p<.05)$, which is a finding in the opposite direction to that found in dualist regimes. Hypothesis 3 is therefore confirmed.

FIGURE 1 HERE

\section{CONCLUSION}

The pattern of cross-national variation in call centre job quality found in this study is largely in accord with that predicted by employment regime theory. As expected, call centres in inclusivist regime countries (i.e., Denmark, Sweden) typically have higher levels job quality than call centres in dualist regime countries (i.e., Austria, France) and market regime countries (i.e., Canada, UK, US), while call centres in dualist regime countries typically have higher levels of job quality than call centres in market regime countries. Furthermore, within dualist regimes, 
job quality is higher in call centres that are part of a larger organisation than in independent call centres.

The results therefore suggest that national institutional regimes are still sufficiently different and still sufficiently influential to produce cross-national variations in job quality - even in a relatively new sector of the economy such as the call centre industry - and run counter to the suggestion that national institutions are being significantly weakened and homogenised as a result of the internationalization of national economies and regional integration. The results also imply that employment regime theory correctly identifies that institutional regimes in western developed economies can be differentiated according to the nature of their employment and industrial relations policies and the relative capacity of organised labour. For example, call centre job quality appears to be higher in inclusivist regimes compared to other types of regime because employment policies in inclusivist regimes countries seek to promote full employment and extend employment rights to all, and because organised labour's strong capacity to influence decision-making within firms and governments; whereas call centre job quality appears to be lower in dualist regimes than in inclusivist regimes because organised labour has relatively less capacity to influence decision-making and its influence is strong only in areas where it is easier to organise workers (e.g., call centres that are part of larger firms) and because employment policies do not seek to extend employment rights to all workers. The support for employment regime theory implies that varieties of capitalism theory (Hall \& Soskice, 2001) does not provide the most accurate account of cross-national variation in the total level of call centre job quality, as it fails to account for the systematic differences that were found between the Nordic countries and Austria and France, or between call centres within dualist regimes.

Although the results are generally in accord with employment regime theory, two findings did not fit the expected pattern. First, although Germany was classified as a dualist regime country, it has a level of call centre job quality that is similar to that found in inclusivist regimes. However, Germany is similar to other dualist countries, as job quality is significantly higher in call centres that are part of a larger organisation. One interpretation of these results is that, although Germany has a dualist institutional regime, its institutional framework may be more effective at promoting call centre job quality than the institutional frameworks of other dualist countries. Second, in market regimes, call centre job quality is higher in independent call centres than in call centres that are part of a larger organisation. One explanation for this 
unexpected difference is that independent call centres in market regimes might be seeking to differentiate themselves from other call centres by adopting a high-commitment human resource strategy as a means of gaining competitive advantage. Batt (2002) found evidence in the US that those call centres serving mass market customers adopting a high-commitment approach to human resources (with higher quality jobs) were outperforming those call centres serving the mass market but which had adopted low-commitment human resource approach. Thus, independent call centres in market regimes may seek competitive advantage by promoting high quality jobs, whereas independent call centres in dualist regimes may seek competitive advantage by providing lower quality jobs and trying to escape from perceived institutional constraints (Haipeter \& Pernod-Lamattre, 2005). In inclusivist regimes, the institutional framework may be sufficiently strong to prevent call centres from pursuing either of these strategies.

A significant contribution of this paper is that it is the first study to compare the total quality of a job between institutional regimes, unlike previous institutional cross-national studies that have concentrated on specific aspects of job quality. This is important because it could be the case that institutional regimes only influence a certain aspect of a job, or only influence certain aspects in particular jobs. This study suggests that institutional regimes can influence all the key aspect of job quality simultaneously. A further contribution is that the study confirms employment regime theory in a relatively new area of the economy, spread across many different sectors, and in a sample that includes European and non-European countries (the US and Canada). This not only helps to support the contemporary relevance of employment regime theory, it also confirms its appropriateness in new national settings, as previous tests of employment regime theory have been restricted to European samples. Another important contribution of this study is that it provides a new criterion-based procedure for developing weighted job quality measures. A key advantage of this procedure is that it provides a measure of job quality that is in keeping with the definition of job quality, i.e., the extent to which a job has a combination of factors that are likely to promote beneficial outcomes. This contrasts with unweighted measures of job quality that simply reflect the extent to which a job has particular factors irrespective of whether they reflect job quality or not. Indeed, contrary to many studies, the unweighted measure of total job quality failed to provide any evidence of systematic differences in job quality between countries. 
Despite the strengths of this study, such as the large cross-national sample, one potential limitation is that the reports on call centre workers' jobs were derived from managers and thus may not accurately reflect employee's actual jobs due to subjective preferences or lack of knowledge about the job. To counter this possibility, all questionnaire items concerned objective properties of the job (e.g., wage-level, number of days of training) rather than subjective assessments (e.g., pay fairness, quality of training). The survey was also conducted at the establishment-level rather than the corporate level, so that managerial respondents would be more familiar with work and human resource practices in the establishment in which they worked (Gerhart, Wright, McMahan, and Snell 2000). But studies based on employee assessments are also problematic (e.g., biased by individual differences), so studies using either managerial or employee assessments of jobs can be seen to provide complementary perspectives. Indeed, it can be suggested that, as the results of this study are in keeping with the results from employee level studies, the method did not unduly bias the results.

In conclusion, the evidence from this paper indicates that institutions still matter, and that the institutions that have a primary influence on job quality are a country's employment and industrial relations policies and the capacity of organised labour to influence decision-making within firms and within government. Further research on cross national variation in job quality is needed on employee-level data to validate the central findings of this paper.

\section{References}

Batt, R. (2002) Managing customer services: human resource practices, quit rates and sales growth. Academy of Management Journal, 45: 587-97.

Batt, R., \& Nohara, H. (2009). How institutions and business strategies affect wages: A crossnational study of call centres. Industrial and Labor Relations Review, 62: 533-552.

Bosch, G., Lehndorff, S., \& Rubery, J. (2009) (Eds.). European Employment Models in Flux. A Comparison of Institutional Change in Nine European Countries. Basingstoke, Palgrave Macmillan,

Brown, A., Charlwood, A., Forde, C., \& Spencer, D. (2007). Job quality and the economics of New Labour: a critical appraisal using subjective survey data. Cambridge Journal of Economics, 31, 941-971. 
Bustillo, R. M., Fernandez-Macias, E., Antón, J-I., \& Esteve, F. (2009). E pluribus unum? A critical review of job quality indicators. Regulating for Decent Work/International Labour Organisation Conference. 8-10th July, 2009.

Cappelli, P., Bassi, L., Katz, H., Knoke, D., Osterman, P., and Useem, M. (1997). Change at Work. New York, NY: Oxford University Press.

Culpepper, P. D. (1999). The future of the high-skill equilibrium in Germany. Oxford Review of Economic Policy, 15, 43-59.

Culpepper, P. D. \& Thelan, K. (2007). Institutions and Collective Actors in the Provision of Training: Historical and Cross-National Comparisons. In K. U. Mayer \& H. Solga (Eds.) Skill Formation. Interdisciplinary and Cross-National Perspectives (pp:21-49). New York, Cambridge University Press.

Deery, S., Iverson, R., \& Walsh, J. (2002). Work relationships in telephone call centers: Understanding emotional exhaustion and employee withdrawal. Journal of Management Studies, 39, 471-496.

Dobbin, F. \& Boychuk, T. (1999). National Employment Systems and Job Autonomy: Why Job Autonomy Is High in the Nordic Countries and Low in the United States, Canada, and Australia. Organization Studies, 20, 257-91.

Esping-Andersen, G. (1990). The Three Worlds of Welfare Capitalism. Princeton: Princeton University Press.

Finegold, D.\& Soskice, D. (1988). The Failure of Training in Britain: Analysis and Prescription. Oxford Review of Economic Policy, 4, 21-53.

Frenkel, S. J., Korczyniski, M., Shire, K. \& Tam, M. (1999). On the Front Line: Organization of Work in the Information Economy. Ithaca, N.Y., and London: Cornell University Press.

Gallie, D. (2000). The quality of working life: Is Scandinavia different? Working Paper $2000 / 154$.

Gallie, D. (2007). Employment regimes and the quality of work. Oxford. Oxford University Press.

Gallie, D. (2009). Institutional regimes and employee influence at work. Cambridge Journal of Regions, Economy and Society. 1-15. 
Gerhart, B., Wright, P.M., McMahan, G., \& Snell, S. (2000). Measurement Error in Research on Human Resources and Firm Performance: How Much Error Is There and How Does It Influence Size Estimates? Personnel Psychology, 53, 803-34.

Goergen, M., Brewster, C. \& Wood, G. (2009). Corporate governance and training. Journal of Industrial Relations, 61, 459-487.

Green, F. (2006). Demanding Work. The paradox of job quality in the affluent economy. Princeton and Oxford: Princeton University Press.

Griffeth, R. W., Hom, P. W., \& Gaertner, S. (2000). A Meta-Analysis of the Antecedents and Correlates of Employee Turnover: Update, Moderator Tests, and Research Implications for the Next Millennium. Journal of Management, 26, 463-88.

Gustavsen, B. (2007). Work Organization and 'The Scandinavian Model'. Economic and Industrial Democracy, Vol. 28, No. 4, pp. 650-71.

Hall, P. A. \& Soskice, D. (2001). An Introduction to Varieties of Capitalism. In David Soskice, ed., Varieties of Capitalism: The Institutional Foundation of Comparative Advantage, pp. 1-70. New York: Oxford University Press.

Haipeter, T. \& Pernod-Lamattre, M. (2005). Lean banking: Retail and direct banking in France and Germany. In G. Bosch and S. Lehndorff (Eds.), Working in the service sector - a tale from different worlds. London and New York, (pp. 339-371).

Holman, D. (2005). Call Centres. In Holman, D., Wall, T.D., Clegg, C., Sparrow, P., \& Howard, A. (2005). (Eds) Essentials of the New Work Place: A guide to the human impact of modern working practices. Chichester, John Wiley and Sons.

Holman, D., Batt, R., \& Holtgrewe, U (2007). The Global Call Center Report: International perspectives on management and employment. A report of the Global Call Center Research Network. Ithaca, N.Y: Cornell University. www.globalcallcenter.org.

Holman, D., Chissick, C, \& Totterdell, P. (2002). The Effects of Performance Monitoring on Emotional Labor and Well-Being in Call Centers. Motivation and Emotion, 26, 57-81.

Holman, D., Frenkel, S., Sørensen, O., \& Wood, S. (2009). Work design variation and outcome in call centres: Strategic choice and institutional explanations. Industrial and Labor Relations Review. 62, 510-532. 
Humphrey, S. E., Nahrgang, J. D., \& Morgeson, F. P. (2007). Integrating motivational, social, and contextual work design features: A meta-analytic summary and theoretical extension of the work design literature. Journal of Applied Psychology, 92, 1332-1356.

Hyman, R. (2001). Understanding European trade unionism: Between market class and society. London, Sage.

Johnson, J. W. (2001). The relative importance of task and contextual performance dimensions to supervisor judgments of overall performance. Journal of Applied Psychology, 86, 984 996.

Lee, T. W., Mitchell, T. R., Wise, L., \& Fireman, S. (1996). An unfolding model of voluntary employee turnover. Academy of Management Journal, 39, 5-36.

Katz, H. \& Darbishire, O. (2000). Converging Divergences: Worldwide Changes in Employment Systems. Ithaca, N.Y.: ILR Press

Korpi W (2006) Power resources and employer-centered approaches in explanations of welfare states and varieties of capitalism. Protagonists, consenters and antagonists. World Politics 58: 167-206.

Kristensen, P. H. \& Lilja, K. (2010). New Modes of Globalizing: Experimentalist Forms of Economic Organization and Enabling Welfare Institutions. Lessons from the Nordic Countries and Slovenia. Final report of the project "Transnational learning through local experimenting (Translearn), EU-funded $6^{\text {th }}$ Framework program.

Lasonen, J. \& Rauhala, P. (2000). Vocational education and training in the Nordic countries. Ann Arbor, Mi.: Prakken Publications

Leschke, J. \& Watt, A. (2008). Job Quality in Europe. WP2008.07. Brussels, ETUI-REHS. Mandel, H. \& Semyonov, M. (2006). “A Welfare State Paradox: State Intervention and Women's Employment Opportunities in 22 Countries.” American Journal of Sociology $111,1910-49$.

Parker, S., \& Wall, T. D. (1999). Job and work design. London: Sage.

Prais, S. J., Jarvis, V., \& Wagner, K. (1989). Productivity and Vocational Skills in Services in Britain and Germany: Hotels. National Institute Economic Review, Vol. 130, 52-74. Rubery, J., Carroll, M., Cooke, F.L., Grugulis, I., \& Earnshaw, J. (2004). Human Resource Management and the Permeable Organization: The Case of the Multi-Client Call Centre. Journal of Management Studies, 41, 1199-1222. 
Sen, A. K. (1985). Commodities and Capabilities, Amsterdam, North-Holland.

Sprigg, C. A. \& Jackson, P.R. (2006). Call Centers as Lean Service Environments: Job-Related Strain and the Mediating Role of Work Design, Journal of Occupational Health Psychology, 11: 197-212.

Streeck, W. (1991). More uncertainties: German unions facing 1992. Industrial Relations, 30, $317-49$.

Tangian, A. (2007). Is work in Europe decent? A study based on the 4th European survey of working conditions 2005. WSI-Diskussionspapier 157. Dusseldorf, Hans-Böckler-Stiftung.

Taylor, P., Baldry, C., Bain, P., \& Ellis, V. (2003). A unique working environment: Health, sickness and absence management in UK call centres, Work, Employment and Society 17, $435-458$

Taylor, P., Hyman, J., Mulvey, G. and Bain, P. (2002) 'Work Organization, Control and the Experience of Work in Call Centres', Work, Employment and Society, 16, 133-50.

Thelan, K., \& Kume, I. (1999). The effects of globalization on labor revisited: Lessons from Germany and Japan. Politics and Society, 27, 477-505.

Warr, P. B. (1990). The measurement of well-being and other aspects of mental health. Journal of Occupational Psychology, 63, 193-210.

Wallerstein, M. (1999). Wage-Setting Institutions and Pay Inequality in Advanced Industrial Societies. American Journal Of Political Science. 43, 649-680.

Wright, P. \& McMahan, G.C. (1992). Theoretical Perspectives for Strategic Human Resource Management. Journal of Management, Vol. 18, No.2, pp. 295-320.

Wright, T. A., \& Bonett, D. G. (2007). Job satisfaction and psychological well-being as nonadditive predictors of workplace turnover. Journal of Management, 33, 141-160.

Wright, T. A. \& Cropanzano, R. (1998). Emotional exhaustion as a predictor of job performance and voluntary turnover. Journal of Applied Psychology, 83, 486-493. 


\section{Acknowledgements}

I would like to thank Damian Grimshaw for his comments on an earlier version of this paper. The author also acknowledges the financial support of the Economic and Social Research Council, U.K., and the Russell Sage Foundation, U.S.

\section{Biography}

David Holman is a senior lecturer at Manchester Business School, University of Manchester.

His research interests lie in the areas of job design and job quality, as well as in emotions and emotion regulation at work. He is currently part of a large research project on emotion regulation (www.erosresearch.org) and on job quality in Europe (www.walquing.eu). 
Table 1. Dimensions of job quality and measures used

Measure

Mean

Weight

1. Work Organisation

Job Discretion. 6-item scale of the extent to which CSRs had control over procedures and timing of work (Holman et al., 2002) A five-point

scale that ranges from "not at all" to "a great deal was used. Cronbach's alpha $=.77$.

Performance monitoring. A 3-item scale on the extent to which CSRs had their calls monitored. An eight-point scale was used, ranging from

"never" to "daily"

Self-managed teams. Percentage of employees working in self-managed teams converted to binary variable.

Off-line improvement teams. Percentage of employees involved in product improvement teams converted to a binary variable.

Technology. 5-item scale of the use of call centre technologies, e.g., email, relationship management, web-enablement

2. Wage and pay systems

Relative Pay-level. Gross annual pay of the full-time CSR relative to national average gross pay. A score of 1 means that the wage is equal to

national average (OECD, 2006)

Performance-related pay. Dummy variable representing whether individual performance-related pay is used or not.

3. Skills and Development

Initial training. No. of training days for call centre agents in the first year. Log-transformed

On-going training. No. of formal training days for experienced agents per year. Log-transformed

4. Flexibility and Security

Flexible work arrangements. A binary measure of whether employees have access to flexible working arrangements, such as flexi-time

Permanent contracts. Percentage of call centre agents with permanent contracts

5. Collective Representation and Voice

Collective bargaining. A dummy variable reflecting presence of a union agreement

Note: Mean score is that before standardization of measures. Both of the mean training scores are non-transformed scores to aid interpretation. 
Table 2: Correlations between the main study variables

\begin{tabular}{|c|c|c|c|c|c|c|c|}
\hline & 1 & 2 & 3 & 4 & 5 & 6 & 7 \\
\hline 1. Weighted job quality & - & & & & & & \\
\hline 2. Non-weighted job quality & $.23^{* *}$ & - & & & & & \\
\hline 3. Market Regime & $-.30 * *$ & -.04 & - & & & & \\
\hline 4. Inclusivist Regime & $.25^{* *}$ & $.10^{* *}$ & $-.49 * *$ & - & & & \\
\hline 5. Dualist Regime & $.14 * *$ & -.03 & $-.71 * *$ & $-.25 * *$ & - & & \\
\hline 6. Part of a larger organisation & $.05^{*}$ & $.10^{* *}$ & .04 & .00 & -.04 & - & \\
\hline 7. Quit rate & $-.38 * *$ & $-.08 * *$ & $.24 * *$ & $-.12 * *$ & $-.17 * *$ & .00 & - \\
\hline
\end{tabular}


Table 3. Mean levels of job quality between countries

\begin{tabular}{|c|c|c|c|c|c|}
\hline & \multirow{2}{*}{$\begin{array}{c}\text { Weighted Job } \\
\text { Quality } \\
\text { Mean Level }\end{array}$} & \multicolumn{3}{|c|}{ Adjusted Weighted Job Quality ${ }^{1}$} & \multirow{2}{*}{$\begin{array}{c}\text { Unweighted Job } \\
\text { Quality }\end{array}$} \\
\hline & & Mean Level & $\begin{array}{c}\text { Independent } \\
\text { Call Centre }\end{array}$ & $\begin{array}{c}\text { Part of Larger } \\
\text { Organisation }\end{array}$ & \\
\hline \multicolumn{6}{|c|}{ Market Regime } \\
\hline Canada & 50.28 & 51.81 & 54.28 & 51.14 & 47.74 \\
\hline $\mathbf{U K}$ & 50.07 & 48.20 & 51.39 & 47.68 & 44.42 \\
\hline US & 46.12 & 44.44 & 47.34 & 43.82 & 51.00 \\
\hline \multicolumn{6}{|l|}{ Dualist } \\
\hline Austria & 55.57 & 57.60 & 52.76 & 58.23 & 47.60 \\
\hline France & 54.85 & 54.58 & 50.40 & 55.89 & 49.55 \\
\hline Germany & 59.36 & 62.66 & 59.25 & 63.63 & 46.76 \\
\hline \multicolumn{6}{|l|}{ Inclusivist } \\
\hline Denmark & 65.25 & 64.35 & 63.12 & 64.53 & 47.96 \\
\hline Sweden & 63.15 & 61.85 & 61.79 & 61.98 & 58.38 \\
\hline
\end{tabular}

${ }^{1}$ Adjusted means are derived from the ANCOVA analysis. 
Figure 1. Mean levels of job quality in independent call centres and call centres attached to larger organisation

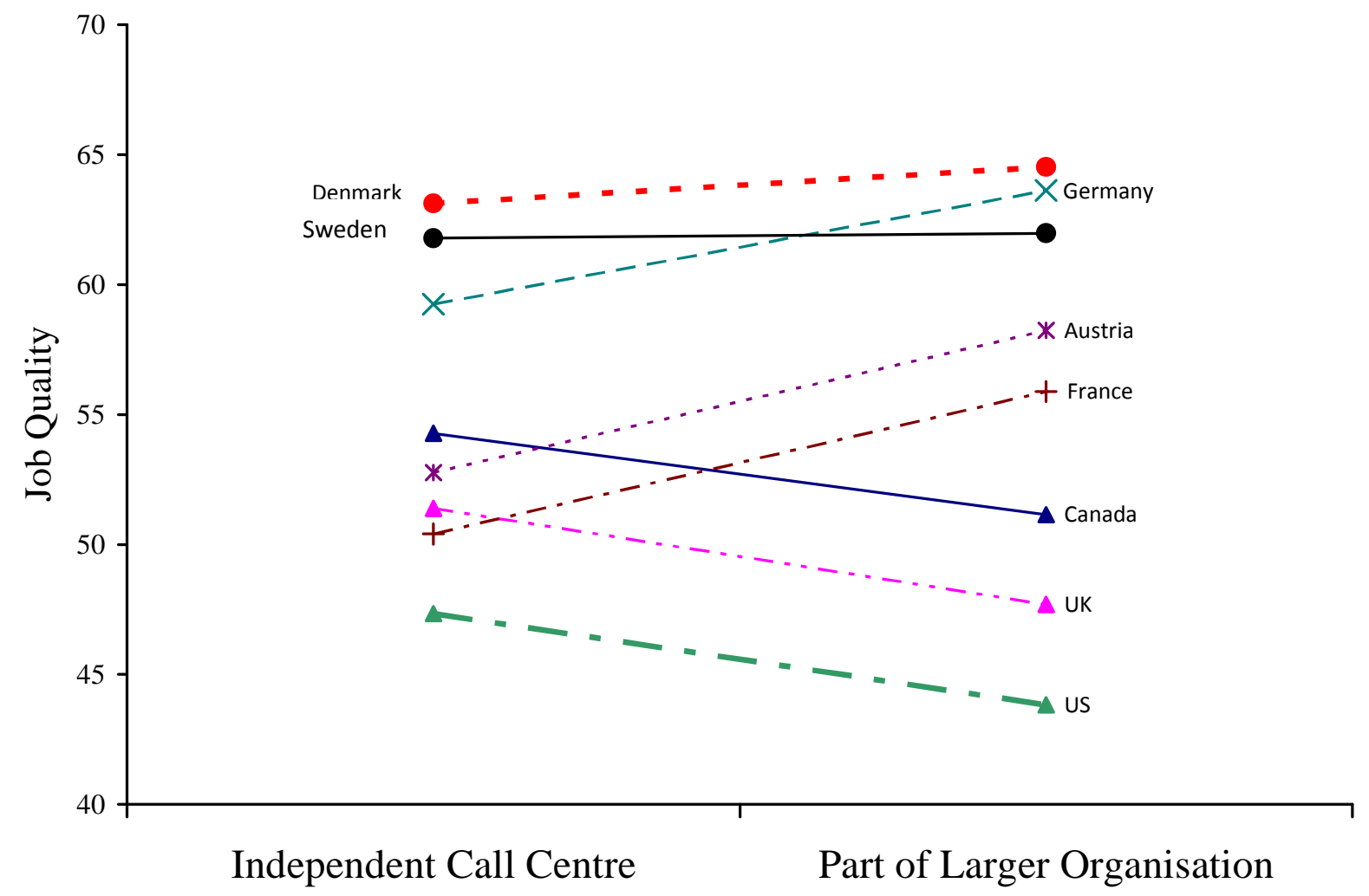

